\title{
SPATIAL PREDICTION AND CLASSIFICATION OF WATER QUALITY PARAMETERS FOR IRRIGATION USE IN THE EUPHRATES RIVER (IRAQ) USING GIS AND SATELLITE IMAGE ANALYSES
}

\author{
H.S. AL-BAHRANI \\ Civil Engineering Department, University of Kufa, Iraq.
}

\begin{abstract}
This study was conducted by analyzing data from satellite image and geographical information system (GIS) to classify water quality parameters of Euphrates River in Iraq for irrigation use.

The main purpose of this research was to develop water quality classification models for Euphrates River, Iraq, using remote sensing. The water quality parameters used in this study included total dissolved solids (TDS), chlorides $\left(\mathrm{Cl}^{-}\right)$, electrical conductivity (EC), and sodium adsorption ratio (SAR). The classification models were used for spatial prediction of these four parameters to determine the water's suitability for irrigation use from the satellite image.

GIS techniques were used in the beginning to project the coordinates of 16 stations along the River in LANDSAT satellite image for Iraq map. Positive strong correlations between digital numbers of the satellite image at Band 2 with the water quality parameters in December, 2009, helped to build four regression models between these two variables. These models could be used to predict these four water quality parameters (TDS, $\mathrm{Cl}^{-}, \mathrm{EC}$, and SAR) at any point along the River in Iraq from the satellite image directly.

The next stage depends on satellite image analyses for the sake of building water quality classification models for Euphrates River on the satellite image to classify each of these water quality parameters according to irrigation use. These water quality classification models can be used to manage the agriculture along the basin of the River and to discover the locations of pollution in the River.

The general objective of this research is attaining a classification model that supports the identification, characterization and monitoring of water quality parameters that have an influence in irrigation.

Keywords: Classification model, Euphrates River, GIS, remote sensing, satellite image water quality.
\end{abstract}

\section{INTRODUCTION}

Euphrates River is a vital resource in Iraq especially for irrigation use. Satellite image analyses and geographical information system (GIS) are important tools to monitor and predict water quality parameters for rivers and lakes. These techniques are quick and cost-effective especially when dealing with geographically wide and inaccessible areas. These techniques were used and well documented in the following literatures.

Al-Bahrani et al. [1] built a water quality classification model on LANDSAT satellite image for Bhargava water quality index on Euphrates River in Iraq. The authors classified the River based on the satellite image into five classes. The classification results were consistent with the values of the water quality index.

Al-Bahrani [2] reported strong negative correlations between digital numbers (DNs) in Bands 1 and 2 of LANDSAT satellite image with water quality indices according to Bhargava and Canadian methods. These two indices were calculated for the Euphrates River from April, 2007 to December, 2010 for 16 stations along the River inside Iraqi lands, and satellite image models were built to classify the water of the River for irrigation use.

Nelson et al. [3] developed a regression model to estimate water clarity as measured by Secchi disk transparency (SDT) from LANDSAT data calibrated using 93 lakes in Michigan, USA. They correlated the natural log of the SDT with the range of LANDSAT DNs of (Band 1/Band 3) and 
discovered that the use of LANDSAT to measure water clarity is sensitive to the distribution of water clarity used in the calibration set.

Sawaya et al. [4] assessed the potential of high-resolution IKONOS and QuickBird satellite imagery for mapping and analysis of land and water resources at local scales in Minnesota in a series of three applications consisting of classifying lake water clarity $\left(r^{2}=0.89\right)$, mapping of urban impervious surface area $\left(r^{2}=0.98\right)$, and surveying aquatic vegetation of emergent and submerging plant groups ( $80 \%$ accuracy).

Selman et al. [5] employed remote sensing with GIS for studying the hydrochemical properties of water at Himreen Dam Reservoir, located on Diyala River in Iraq. Analytical study on spectrum reflectance value of study area was performed using satellite image, taken by LANDSAT.

Al-Rubai'i [6] used thermal technique of remote sensing to evaluate its capability to detect and identify water pollution that results from petroleum-related pollution. A mathematical model was developed using DNs of thermal satellite images to measure the temperature of water.

The aim of this study is to predict the spatial distribution of water quality parameters using satellite images.

\section{METHODS}

Water pollution can be defined in general as 'any variation either natural or artificial that changes the quality of water and disturbs or destroys the balance of ecosystems and natural sources, so that it: causes hazards to public health, detracts from the convenience efficiency and wellbeing of man and his communities, and impairs the beneficial uses of water' [7].

There are four main water quality parameters, which increased have adverse effects on water quality especially for irrigation use. These four parameters are: total dissolved solids (TDS), electrical conductivity (EC), sodium adsorption ratio (SAR), and chlorides $\left(\mathrm{Cl}^{-}\right)$.

The classification of these water quality parameters for irrigation use is shown in Table 1. TDS is classified into four classes for irrigation use according to the American Salt Laboratory [2]. These classifications begin from $0 \mathrm{mg} / \mathrm{l}$ and end at $3200 \mathrm{mg} / \mathrm{l}$, where after this concentration the water becomes not suitable for irrigation.

Electrical conductivity classified for irrigation use into five classes begins from $<0.25 \mathrm{ds} / \mathrm{m}$ and ends at $3.0 \mathrm{ds} / \mathrm{m}[8]$.

SAR is considered one of the most important hydro-chemical parameters, which reflects the effect of the sodium on the irrigation water [9]. It is calculated by using Gapon equation [10] as follows:

$$
S A R=\frac{N a^{+}}{\sqrt{\frac{\left(C a^{++}+M g^{++}\right)}{2}}}
$$

The ionic concentrations in eqn above are expressed in milliequivalent per liter (meq/L). Sodium in irrigation water can also cause toxicity problems for some crops, especially when sprinkler applied [8].

Chloride is essential to plants in very low amounts; it can cause toxicity to sensitive crops at high concentrations [11]. The presence of chlorides in surface waters can be of natural origin from rainwater and molten snow or due to salt from agriculture, sewage, and industrial waste effluents. At excessive concentrations, chloride is a hazard, causing rapid corrosion in pipes and boilers and damaging crops [12].

LANDSAT satellite images were merged together to make one mosaic digital image for Iraq map consisting of three bands: Bands 1, 2, and 3. The ranges of wavelength for Bands 1, 2, and 3 are $(0.45-0.52),(0.52-0.60)$, and $(0.63-0.69) \mu \mathrm{m}$, respectively. 
Table 1: Classification of water quality parameters for irrigation use.

\begin{tabular}{|c|c|c|c|}
\hline Parameter & Class & Threshold value & Comment \\
\hline \multirow[t]{4}{*}{$\begin{array}{l}\text { Total dissolved } \\
\text { solids (TDS) } \\
(\mathrm{mg} / \mathrm{L})\end{array}$} & $\mathrm{C} 1$ & $0-160$ & $\begin{array}{l}\text { Less salt: water is appropriate to most plants } \\
\text { and lands with a little possibility of land } \\
\text { saltiness }\end{array}$ \\
\hline & $\mathrm{C} 2$ & $161-480$ & $\begin{array}{l}\text { Moderate salt: water is appropriate to plants } \\
\text { that can undergo salts increase where there is } \\
\text { moderate draining for the land }\end{array}$ \\
\hline & $\mathrm{C} 3$ & $481-1440$ & $\begin{array}{l}\text { High salt: water is appropriate for plants that } \\
\text { resist salts and on well-drained lands. It is } \\
\text { necessary to have a good draining system for } \\
\text { the land }\end{array}$ \\
\hline & $\mathrm{C} 4$ & $1441-3200$ & $\begin{array}{l}\text { Very high salt: water is appropriate for plants } \\
\text { that are highly resistance to salts and on } \\
\text { pervasive well-drained lands and deep washing } \\
\text { for salts }\end{array}$ \\
\hline \multirow{4}{*}{$\begin{array}{l}\text { Chlorides }\left(\mathrm{Cl}^{-}\right) \\
(\mathrm{mg} / \mathrm{L})\end{array}$} & $\mathrm{C} 1$ & $<70$ & Generally safe for all plants \\
\hline & $\mathrm{C} 2$ & $70-140$ & Sensitive plants show injury \\
\hline & $\mathrm{C} 3$ & $141-350$ & Moderately tolerant plants show injury \\
\hline & $\mathrm{C} 4$ & $>350$ & Can cause severe problems \\
\hline \multirow{4}{*}{$\begin{array}{l}\text { Sodium adsorption } \\
\text { ratio }(\mathrm{SAR}) \\
(\mathrm{meq} / \mathrm{L})\end{array}$} & $\mathrm{C} 1$ & $1-9$ & $\begin{array}{l}\text { Low: use on sodium-sensitive crops must be } \\
\text { cautioned }\end{array}$ \\
\hline & $\mathrm{C} 2$ & $10-17$ & $\begin{array}{l}\text { Medium: amendments (such as gypsum) and } \\
\text { leaching needed }\end{array}$ \\
\hline & $\mathrm{C} 3$ & $18-25$ & High: generally unsuitable for continuous use \\
\hline & $\mathrm{C} 4$ & $\geq 26$ & Very high: generally unsuitable for use \\
\hline \multirow{5}{*}{$\begin{array}{l}\text { Electrical } \\
\text { conductivity }(\mathrm{EC}) \\
(\mathrm{ds} / \mathrm{m})\end{array}$} & $\mathrm{C} 1$ & $<0.25$ & Excellent \\
\hline & $\mathrm{C} 2$ & $0.25-0.75$ & Good \\
\hline & $\mathrm{C} 3$ & $0.76-2.00$ & Permissible: leaching needed if used \\
\hline & $\mathrm{C} 4$ & $2.01-3.00$ & $\begin{array}{l}\text { Doubtful: good drainage needed and sensitive } \\
\text { plants will have difficulty obtaining stands }\end{array}$ \\
\hline & C5 & $>3.00$ & Unsuitable \\
\hline
\end{tabular}

Coordinates of 16 stations for Euphrates River were projected and mapped on the mosaic LANDSAT image as shown in Fig. 1. Al-Qaim station represents the first station when the River leaves Syria and enters to Iraq, whereas Qurna station represents the last station in Euphrates River before its union with Tigris River to make Shatt Al-Arab River, ends at last in the Gulf.

Signature editor technique in the software ERDAS Imagine 8.4 was used to find the DNs at Bands 1, 2, and 3 for each station along Euphrates River in the satellite image. Table 2 illustrates the values of the DNs in Bands 1, 2, and 3 and the values of the four water quality parameters at December, 2009 for each station along the River. 


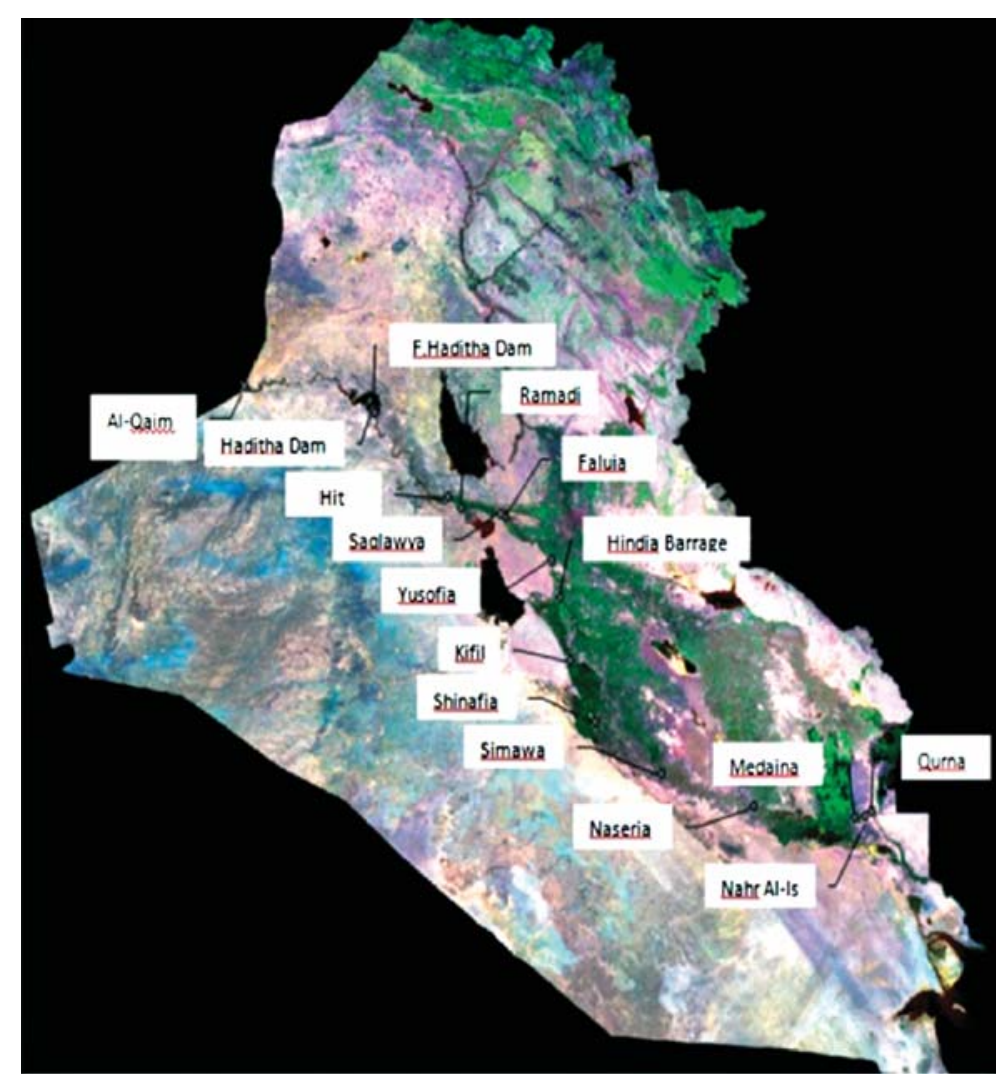

Figure 1: Euphrates River stations projected on Iraq Mosaic LANDSAT satellite image [2].

\section{RESULTS}

Pearson correlation coefficients were computed between the DNs of the three bands for Iraq mosaic LANDSAT satellite image and the four water quality parameters for the 16 monitoring stations of Euphrates River on December, 2009 as shown in Table 3 [13].

The results indicate that the four water quality parameters have statistically significant correlations with DNs at Band 1 and Band 2, whereas the correlations were statistically not significant with DN at Band 3, and with DN ratios of (Band 1/Band 3) and (Band 2/Band 3). It is clear from Table 3 that DNs at Band 2 have the best relationship with the four water quality parameters, and this means that the reflectance for these four parameters increases in the wave lengths $(0.52-0.60 \mu \mathrm{m})$, which represent Band 2 in the satellite image.

\section{REGRESSION MODELS}

Four linear regression models for the four water quality parameters on DNs of Band 2 at confidence 0.99 were built as shown in Table 4, where $\mathrm{DN}_{2}$ represented the DNs of the satellite image at Band 2. These regression models could be used to predict the water quality parameters from the DNs of Band 2 in the satellite image at any point along the River inside Iraqi land. Figure 2 represents the scatter diagram of TDS and DNs in Band 2 with the best regression line passed through these points.

ANOVA test was used to measure the goodness of estimation regression parameters $a$ and $b$ for the four linear regression models. When the calculated statistic $F$ is greater than the tabulated 
Table 2: Digital numbers and water quality parameters of Euphrates River stations for Iraq Mosaic LANDSAT satellite image.

\begin{tabular}{|c|c|c|c|c|c|c|c|}
\hline \multirow[b]{2}{*}{ Station } & \multicolumn{3}{|c|}{ Digital numbers (DNs) } & \multirow[b]{2}{*}{$\begin{array}{l}\text { TDS } \\
(\mathrm{mg} / \mathrm{l})\end{array}$} & \multirow[b]{2}{*}{$\begin{array}{l}\mathrm{Cl}^{-} \\
(\mathrm{mg} / \mathrm{l})\end{array}$} & \multirow[b]{2}{*}{$\begin{array}{l}\mathrm{EC} \\
(\mathrm{dS} / \mathrm{m})\end{array}$} & \multirow[b]{2}{*}{$\begin{array}{l}\text { SAR } \\
\text { (meq/l }\end{array}$} \\
\hline & $\begin{array}{l}\text { Band } 1 \\
(0.45-0.52) \\
\mu \mathrm{m}\end{array}$ & $\begin{array}{l}\text { Band } 2 \\
(0.52-0.60) \\
\mu \mathrm{m}\end{array}$ & $\begin{array}{l}\text { Band } 3 \\
(0.63-0.69) \\
\mu \mathrm{m}\end{array}$ & & & & \\
\hline Al-Qaim & 0 & 0 & 22 & 582 & 83 & 0.85 & 1.9 \\
\hline F. Haditha Dam & 9 & 8 & 19 & 620 & 101 & 0.94 & 2.2 \\
\hline Haditha Dam & 8 & 12 & 3 & 746 & 126 & 1.12 & 2.5 \\
\hline Hit & 2 & 12 & 15 & 820 & 154 & 1.25 & 2.7 \\
\hline Ramadi & 0 & 15 & 31 & 964 & 172 & 1.36 & 2.7 \\
\hline Saqlawia & 10 & 22 & 47 & 944 & 160 & 1.39 & 2.8 \\
\hline Faluja & 9 & 20 & 37 & 940 & 163 & 1.36 & 2.6 \\
\hline Yosufia & 7 & 11 & 38 & 936 & 151 & 1.35 & 2.3 \\
\hline Hindia Barrage & 1 & 7 & 20 & 907 & 167.5 & 1.3675 & 2.225 \\
\hline Kifil & 0 & 11 & 19 & 942 & 181 & 1.5 & 2.4 \\
\hline Shinafia & 7 & 50 & 9 & 2670 & 706 & 3.8 & 6.4 \\
\hline Simawa & 13 & 23 & 34 & 2600 & 710 & 3.8 & 6.7 \\
\hline Naseria & 37 & 47 & 77 & 3370 & 1015 & 4.8 & 8.8 \\
\hline Medaina & 7 & 21 & 24 & 1680 & 497 & 2.64 & 6.5 \\
\hline Nahr Al-Is & 5 & 23 & 15 & 1505 & 479 & 2.54 & 7 \\
\hline Qurna & 9 & 12 & 42 & 838 & 208 & 1.44 & 2.9 \\
\hline
\end{tabular}

Table 3: Correlation coefficients of DNs and water quality parameters at December, 2009 for Euphrates River stations in Iraq.

\begin{tabular}{lccccc}
\hline Water quality parameters & Band 1 & Band 2 & Band 3 & B1/B3 & B2/B3 \\
\hline Total dissolved solids & $0.717^{*}$ & $0.885^{*}$ & 0.422 & 0.052 & 0.324 \\
Chlorides & $0.725^{*}$ & $0.863^{*}$ & 0.415 & 0.048 & 0.292 \\
Electrical conductivity & $0.701^{*}$ & $0.875^{*}$ & 0.402 & 0.043 & 0.315 \\
Sodium adsorption ratio & $0.645^{*}$ & $0.809^{*}$ & 0.323 & 0.056 & 0.278 \\
\hline
\end{tabular}

*Correlation is significant at the 0.01 level (two-tailed), B1 = Band 1, B2 = Band 2, and B3 = Band 3 .

Table 4: Regression models of water quality parameters of Euphrates River on digital numbers at Band 2 of Iraq mosaic satellite image at December, 2009.

\begin{tabular}{llccc}
\hline Water quality parameter & \multicolumn{1}{c}{ Regression model } & $R^{2}$ & $n-p$ & $F_{\text {calculated }} / F_{\text {tabulated }}$ \\
\hline Total dissolved solids & $\mathrm{TDS}=300.565+55.289 \mathrm{DN}_{2}$ & 0.783 & 14 & 5.68 \\
Chlorides & $\mathrm{Cl}=-12.163+17.9187 \mathrm{DN}_{2}$ & 0.744 & 14 & 4.58 \\
Electrical conductivity & $\mathrm{EC}=0.5393+0.0778 \mathrm{DN}_{2}$ & 0.766 & 14 & 5.14 \\
Sodium adsorption ratio & $\mathrm{SAR}=1.3933+0.1372 \mathrm{DN}_{2}$ & 0.654 & 14 & 2.98 \\
\hline
\end{tabular}




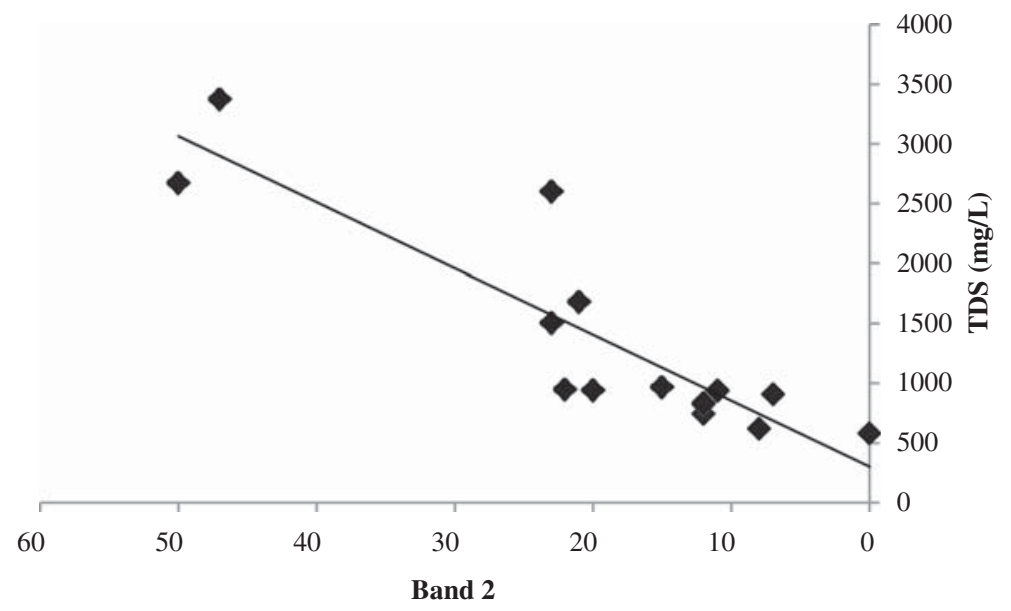

Figure 2: Scatter diagram of total dissolved solids (TDS) and digital numbers (DNs) in Band 2 for Euphrates River stations on September, 2009.

$F[0.99 ; 1, n$-p] from $F$-table, this means that the regression model is accurate, where $n$ represents the number of monitoring stations on the River, and $p$ represents the number of regression parameters in the model. After application of the ANOVA test on the four linear regression models illustrated in Table 4, the four models passed the test successfully at 0.99 confidence limit.

\section{BUILDING THE SATELLITE IMAGE MODELS}

Four satellite image models were built for TDS, $\mathrm{EC}, \mathrm{Cl}^{-}$, and SAR water quality parameters of the Euphrates River. The ERDAS Imagine 8.4 Software - specifically, isodata unsupervised classification is used to determine the water areas for the Euphrates River Basin within the mosaic satellite image of Iraq. These areas are represented by blue color in Fig. 3 .

The water areas on the satellite image are colored according to the classifications for irrigation use of the four water quality parameters (Table 1) using the regression models for DNs of Band 2. The limits that were presented in Table 1 were used to determine the bounds of the DNs for each of the classes.

Figure 4 represents the water quality classification model of Euphrates River in Iraq according to TDS classifications for irrigation use. The River in the satellite image is classified into four colors: beige, represents the less salt; yellow, represents moderate salt; purple, represents high salt; and brown color, represents very high salt. It is noticed from the figure that purple and brown colors are more spread than beige and yellow colors. This result gives an estimation that the water in basin of Euphrates River in Iraq was classified as high and very high salt during December, 2009. This model clarifies that the water of Euphrates River inside Iraq upstream of Shinafia station is appropriate for plants that resist salts because it is classified as high salt (481-1440 ppm) in most places, whereas the water of the River downstream of Shinafia station is appropriate only for plants that are highly resistance to salts because it is classified as very high salt (1441-3200 ppm). The water quality of the River begins to improve downstream of Nahr Al-Is station because of mixing with water of Tigris River at these stations. Accordingly, the water quality classification (based on TDS) of Euphrates River downstream of Nahr Al-Is station shows improvement.

Figure 5 represents the water quality classification model of Euphrates River in Iraq using EC classifications for irrigation use. The River in the satellite image is classified into five colors: blue, 


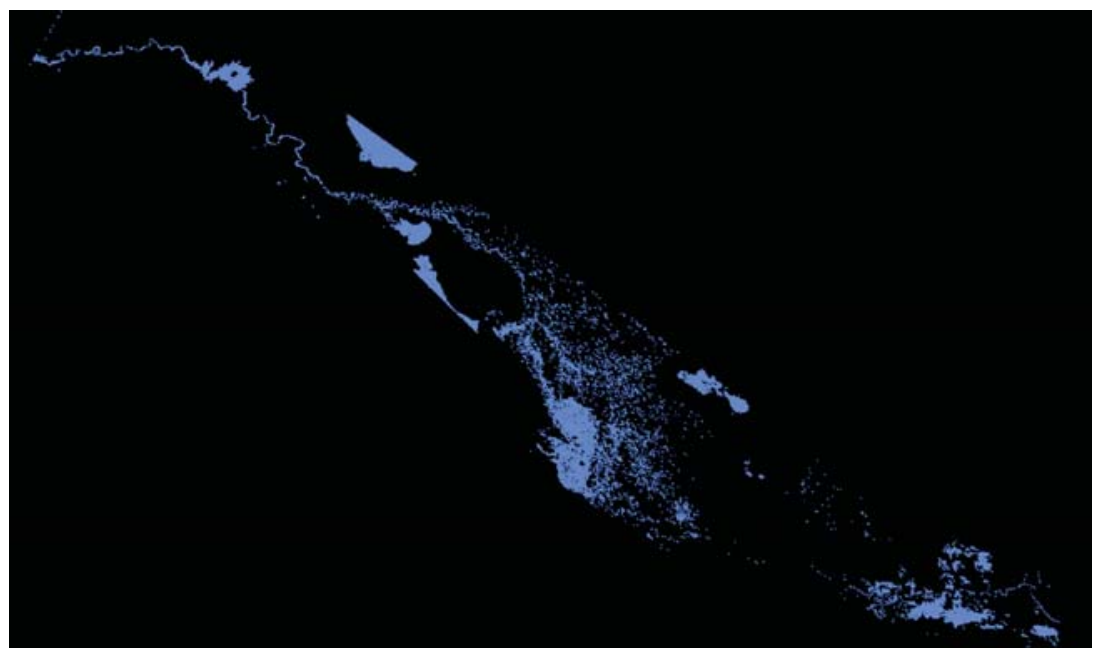

Figure 3: Water areas for the basin of Euphrates River in Iraq mosaic satellite image.

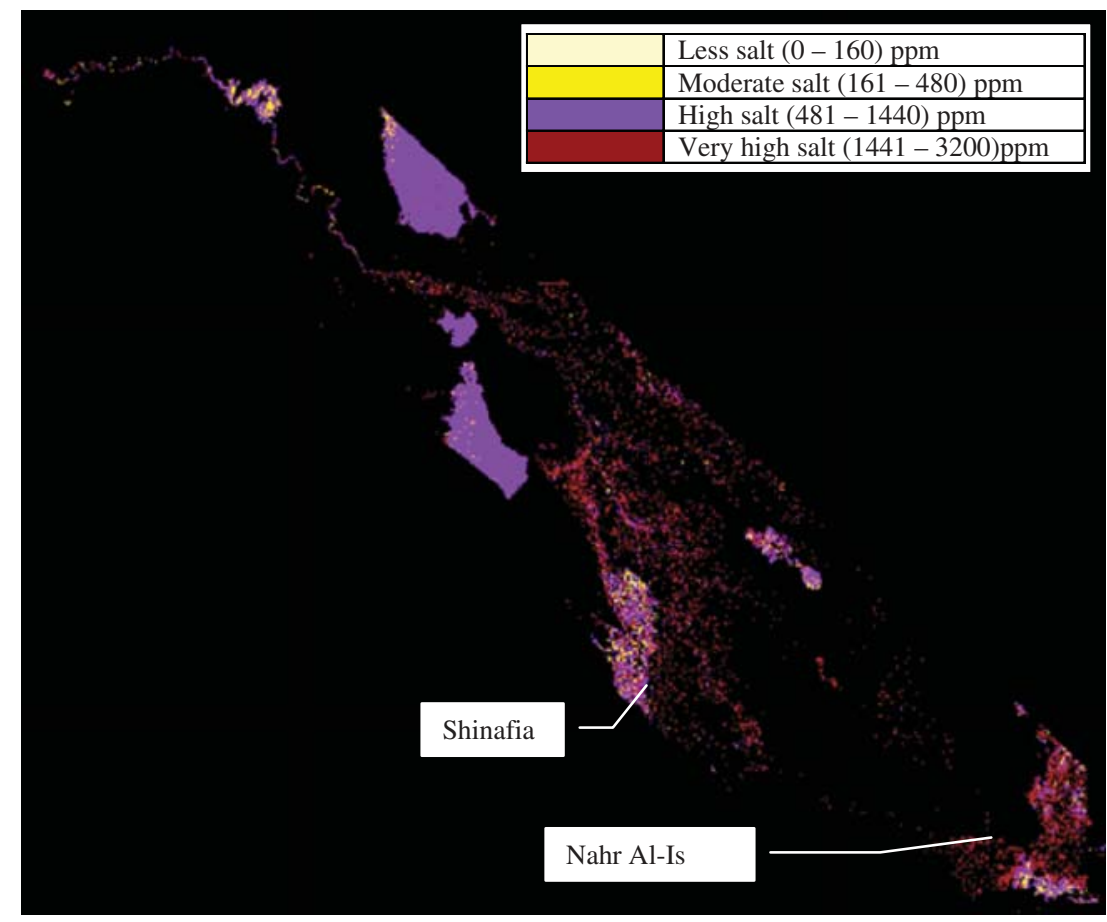

Figure 4: Water quality classification model of total dissolved solids (TDS) parameter for the basin of Euphrates River in Iraq according to irrigation classifications. 


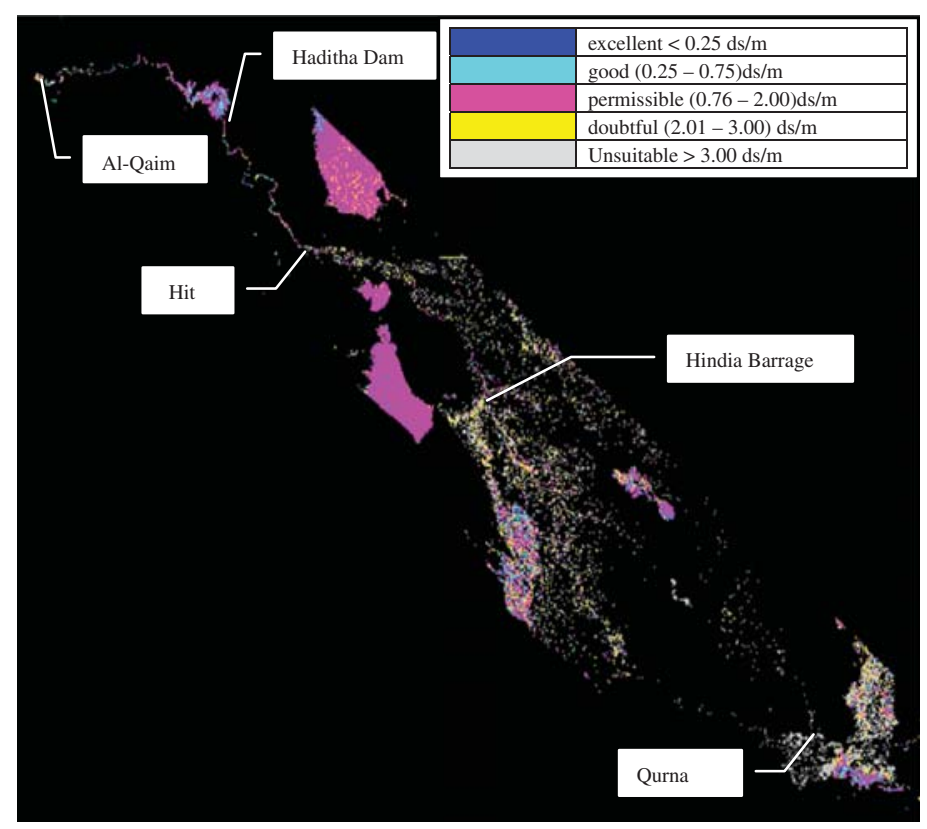

Figure 5: Water quality classification model of electrical conductivity (EC) parameter for the basin of Euphrates River in Iraq according to irrigation classifications.

represents excellent water; cyan, represents good water; magenta, represents permissible water; yellow, represents doubtful water; and gray color, represents unsuitable water. According to these five colors, the basin of the River could be classified into four regions: cyan color $(0.25-0.75 \mathrm{ds} / \mathrm{m})$, from Al-Qaim station to Haditha Dam station; magenta color $(0.76-2.00 \mathrm{ds} / \mathrm{m})$, from Haditha Dam station to Hit station, yellow color (2.01-3.00 ds/m), from Hit station to Hindia Barrage station; and gray color $(>3.00 \mathrm{ds} / \mathrm{m})$ from Hindia Barrage station to Qurna station. These results indicate that the water quality for irrigation use of the River deteriorates the farther downstream of the River. Accordingly, using the classification system shown in Table 1 (relative to EC), the River segments are classified into the following classes: good for the segment between Al-Qaim and Haditha Dam stations; permissible for the segment between Haditha Dam and Hit stations; doubtful for the segment between Hit and Hindia Barrage stations, and unsuitable for the segment between Hindia Barrage and Qurna stations.

Figure 6 represents the water quality classification model of Euphrates River in Iraq based on chlorides classifications for irrigation use. The River in the satellite image is classified into four colors: tan, represents 'safe water for all plants'; green, represents 'sensitive plants show injury', purple, represents 'moderately tolerant plants show injury'; and dark green, represents 'cause severe problems'. It is seen from the figure that the tan color spread northern Hit station and between Yosufia and Kifil stations. This means that the water quality in these places of the River is safe for all plants (based on chlorides). The dark green color is more prevalent in most regions downstream of Shinafia station indicating that the concentration of chlorides can cause severe problems for plants.

The classifications of SAR for irrigation water quality of Euphrates River on December, 2009 are represented in Fig. 7. The gold color in the figure represents low SAR, and this color spreads in the River from its entrance to the Iraqi land at Al-Qaim station until Kifil station. Also, this color exists in the River downstream of Medaina station to Qurna station. The green color represents medium 


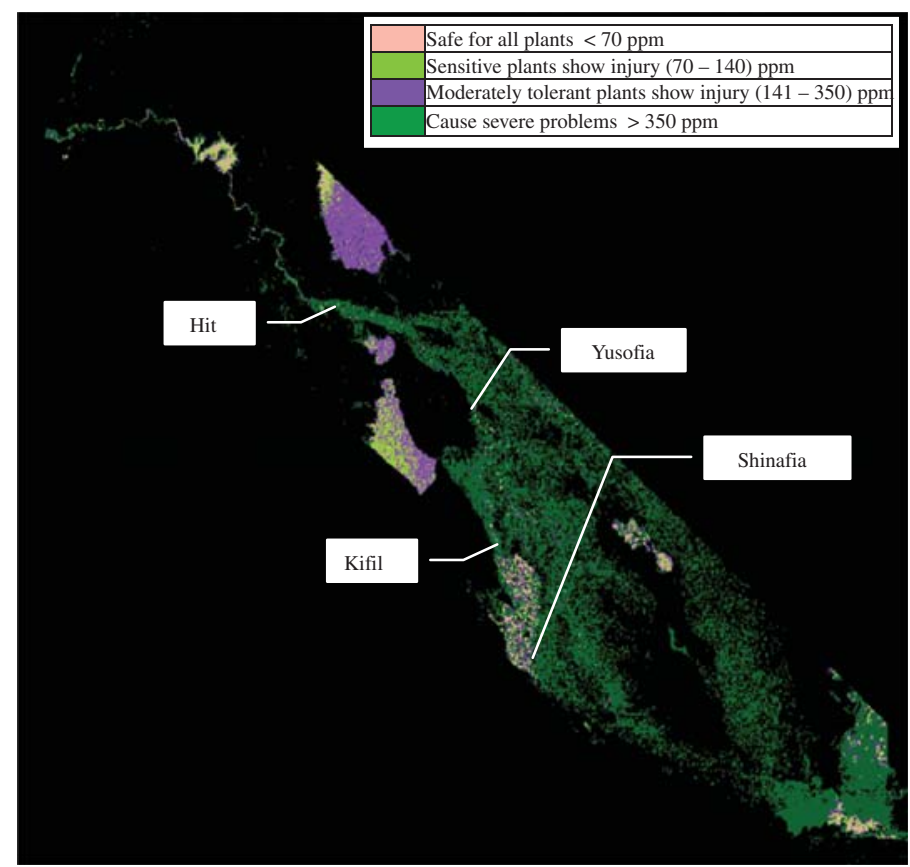

Figure 6: Water quality classification model of chlorides $\left(\mathrm{Cl}^{-}\right)$parameter for the basin of Euphrates River in Iraq according to irrigation classifications.

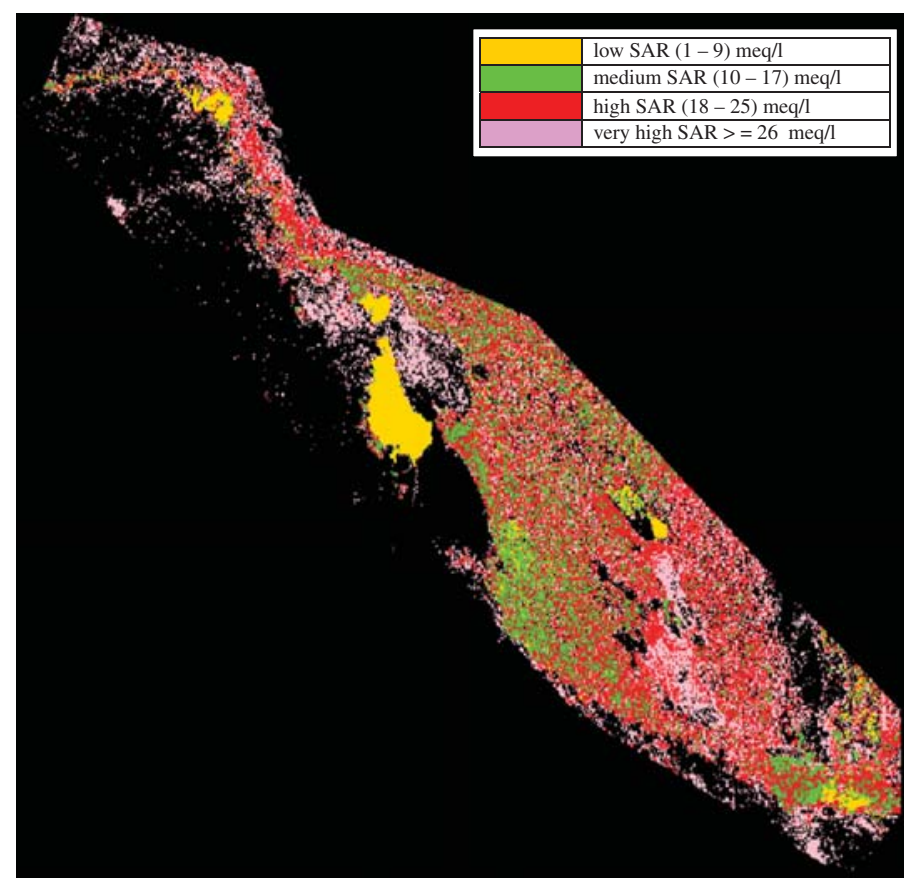

Figure 7: Water quality classification model of sodium adsorption ratio (SAR) parameter for the basin of Euphrates River in Iraq according to irrigation classifications. 

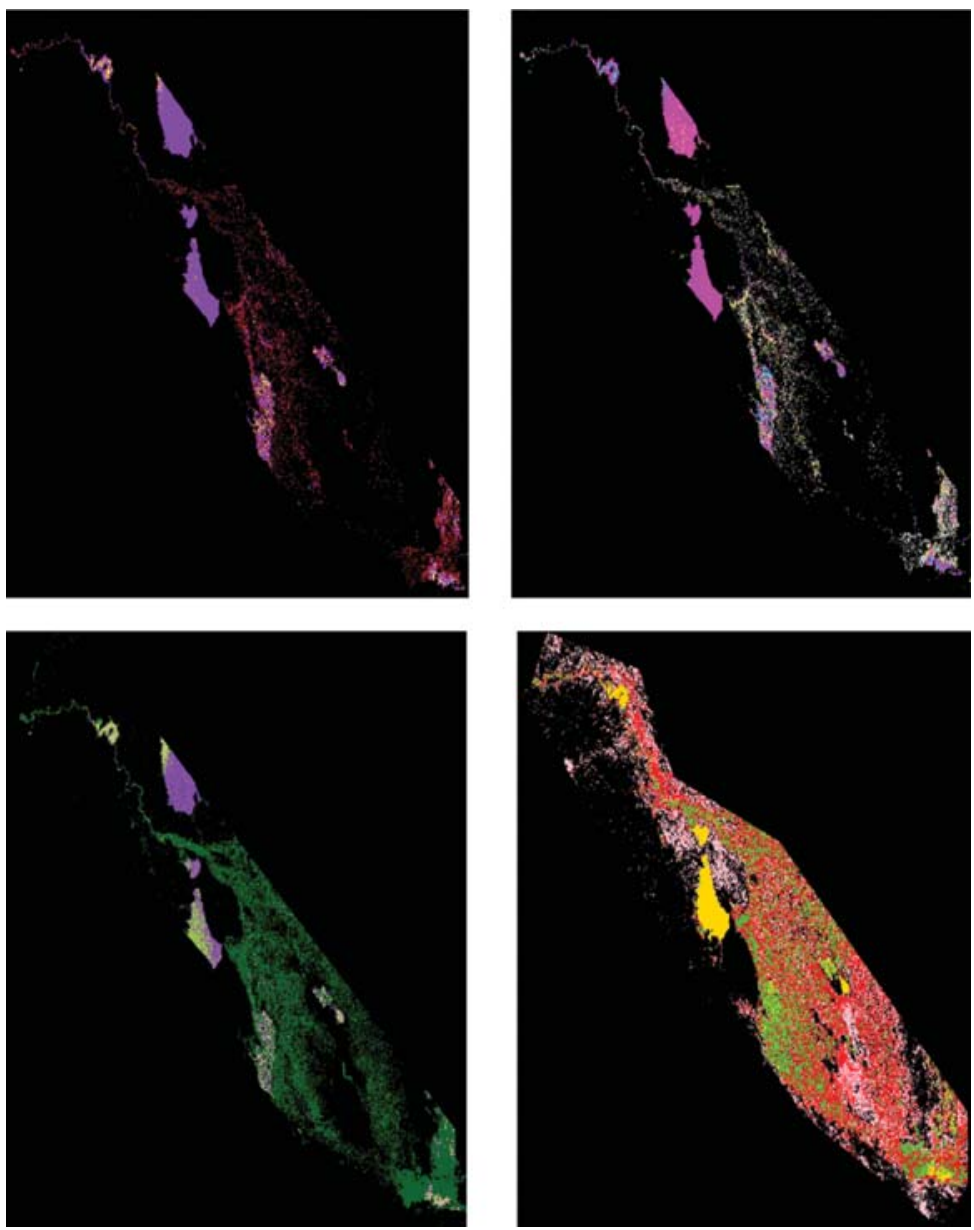

Figure 8: Water quality classification models of the four water quality parameters for the basin of Euphrates River in Iraq according to irrigation classifications.

SAR of water in the figure; this color is spread downstream of Kifil station to Shinafia station. Red and pink colors represent waters that are classified as high and very high SAR; these colors are spread in the Euphrates River downstream of Shinafia station to Medaina station. Also, it is seen that the values of SAR for lakes beside the River are low and non-detect.

Combining the four water quality classification models in one composite figure helps identifying the parameters and their classes in various reaches of the River as shown in Fig. 8. This comparison helps to determine the suitability of each agriculture regions for different crops along the Euphrates River Basin.

\section{CONCLUSIONS AND RECOMMENDATIONS}

Based on the results of this study, it was demonstrated that remote sensing and satellite image analyses can be used for environmental monitoring, and spatial prediction of water quality parameters for Euphrates River in Iraq for the purpose of irrigation water use. This objective was achieved utilizing water quality classification models for four parameters. 
It is recommended that the methodology proposed in this study should be used to develop models for other streams and lakes. This methodology can be further extended by using higher resolution images taken from other satellites such as SPOT, Quick Bird, and IKONOS.

This study demonstrated that the water quality of Euphrates River is not suitable for agriculture of sensitive crops such as fruits especially the regions from Shinafia station in the southern reach of the River to Qurna station.

\section{ACKNOWLEDGEMENTS}

A lot of thanks and appreciations to WIT's reviewers. Their comments help to develop and improve the research. Also I thank Prof. Ramzi Mahmood from California State University for reviewing the language of the research.

\section{REFERENCES}

[1] Al-Bahrani, H.S., Abdul Razzaq, K.A. \& Saleh, S.A.H., Remote sensing of water quality index for irrigation usability of Euphrates river, Water Pollution XI, C.A. Brebbia, Wessex Institute of Technology, UK, 2012, WIT Transactions on Ecology and The Environment, vol 164, (C) 2012 WIT Press www.witpress.com, ISSN 1743-3541 (on-line). doi:10.2495/WP 120051.

[2] Al-Bahrani, H.S., A satellite image model for predicting water quality index of Euphrates River in Iraq, PhD thesis, Environmental Engineering Department, University of Baghdad, Iraq, 2012.

[3] Nelson, S.A.C., Soranno, P.A., Cherueil, K.S., Batzli, S.A. \& Skole, D. L., Regional assessment of lake water clarity using satellite remote sensing. Journal of Limnology, 62(1), pp. 27-32, 2003.

[4] Sawaya, K.E., Olmanson, L.G., Heinert, N.J., Brezonik, P.L. \& Bauer, M.E., Extending satellite remote sensing to local scales: land and water resource monitoring using high resolution imagery. Journal of Remote Sensing of Environment, 88, pp. 144-156, 2003. doi: http://dx.doi. org/10.1016/j.rse.2003.04.006

[5] Selman, N.M., Salih, S.A.H. \& Al-Samawi, A., A study on suspended sediment distribution in Himreen Reservoir using remote sensing techniques, MSc thesis, Building and Construction Engineering Department, University of Technology, Iraq, 2006.

[6] Al-Rubai'i, H.I., Evaluation of thermal behavior of oil storage tanks using remote sensing techniques for environmental pollution purposes, MSc thesis, Building and Construction Engineering Department, University of Technology, Iraq, 2006.

[7] UNESCO, IHP, Dispersion and self-purification of pollutants in surface water systems, UNESCO. Paris, Technical Paper in Hydrology, 1982.

[8] Bauder, T.A., Waskom, R.M., \& Davis, J.G., Irrigation Water Quality Criteria, no. 0.506, Colorado State University, http://www.colostate.edu/, 2010.

[9] Todd, D.K., Ground Water Hydrology, John Wiley and Sons, Inc.: New York, 1980.

[10] Kelly, W.P., Cation Exchange in Soils, A.C.S. Monograph No. 109, Reinhold: New York, USA, 1948.

[11] Mass, E.V., Crop salt tolerance. Agricultural Salinity Assessment and Management Manual, K.K. Tanji, ed., ASCE: New York, pp. 262-304, 1990.

[12] Todd, D.K., The Water Encyclopedia, John Wiley, Inc.: New York, 1970.

[13] SPSS, SPSS tower guide, SPSS 9.0 for Windows, SPSS Inc., 1999. 